\title{
Development of a diagnostic test for the Midlands 1 cystic fibrosis epidemic strain of Pseudomonas aeruginosa
}

\section{Correspondence \\ Craig Winstanley \\ C.Winstanley@liv.ac.uk}

Received 2 March 2006

Accepted 28 April 2006

\author{
Catherine H. M. Smart, ${ }^{1}$ Fiona W. Scott, ${ }^{2}$ Elli A. Wright, ${ }^{1}$ Martin J. Walshaw, ${ }^{3}$ \\ C. Anthony Hart, ${ }^{1}$ Tyrone L. Pitt ${ }^{2}$ and Craig Winstanley ${ }^{1}$ \\ ${ }^{1}$ Division of Medical Microbiology and Genitourinary Medicine, University of Liverpool, \\ Duncan Building, Daulby Street, Liverpool L69 3GA, UK \\ ${ }^{2}$ Laboratory of HealthCare Associated Infection, Health Protection Agency, 61 Colindale \\ Avenue, London NW9 5HT, UK \\ ${ }^{3}$ Regional Adult Cystic Fibrosis Unit, Cardiothoracic Centre, Liverpool L14 3PE, UK
}

\section{INTRODUCTION}

Pseudomonas aeruginosa is the most common bacterial pathogen associated with morbidity and mortality in cystic fibrosis (CF), causing chronic lung infections that, once established, are impossible to eradicate. The general view that individual CF patients acquire $P$. aeruginosa infections separately, and thus carry their own unrelated strains, was challenged in 1996 when the spread of a multi-drugresistant strain of $P$. aeruginosa [named the Liverpool epidemic strain (LES)] amongst patients in a children's CF centre in Liverpool was reported (Cheng et al., 1996). Since then, there have been further reports of CF 'epidemic' strains (Jones et al., 2001; Armstrong et al., 2003; O'Carroll et al., 2004), raising serious questions about whether segregation strategies might be required to counter transmission. A survey of $31 \mathrm{CF}$ centres in England and Wales, in which over 1200 isolates of $P$. aeruginosa were analysed, not only identified LES as the most common clone, being present in $48 \%$ of CF centres and accounting for $11 \%$ of the isolates, but also identified other strains with a wide distribution amongst CF patients in England and Wales (Scott \& Pitt,

Abbreviations: CF, cystic fibrosis; LES, Liverpool epidemic strain; SSH, suppression subtractive hybridization.
2004). In particular, the Midlands 1 clone represented $10 \%$ of the isolates and was present in $29 \%$ of the CF centres. Thus, the two most common genotypes (LES and Midlands 1) accounted for $21 \%$ of isolates examined and were found in $58 \%$ of CF centres (Scott \& Pitt, 2004). A strain reported as epidemic amongst CF patients in Manchester (Jones et al., 2001) was not widely distributed and represented only $1 \%$ of the isolates in the study (Scott \& Pitt, 2004). More recently, the Midlands 1 clone was reported to be present in $30 \%$ of $P$. aeruginosa-positive CF patients in an adult CF unit in the West Midlands (Chambers et al., 2005).

The 'gold-standard' typing method for identification of epidemic strains, macrorestriction analysis using PFGE, is time-consuming and requires specialist equipment. Thus, rapid PCR-based assays for the identification of epidemic strains would be of considerable benefit to CF units. Previously, we have used suppression subtractive hybridization ( $\mathrm{SSH})$, a technique that enables the identification of sequences present in one strain but absent from another (Winstanley, 2002), to identify strain-specific sequences. These data were used to develop PCR-based diagnostic tests for the LES (Parsons et al., 2002; Panagea et al., 2003; Smart et al., 2006). In this study, we report the use of SSH to identify sequences unique to the Midlands 1 clone. By this 
approach, we were able to gain insight into the accessory genome or mobilome (Ou et al., 2005) and to design a PCR-based test for identification of this CF epidemic strain.

\section{METHODS}

Bacterial strains. The Midlands 1 isolate used in SSH (isolate 9245) was originally isolated at Birmingham Heartlands Hospital, UK, and was chosen from isolates identified in a previous study (Scott \& Pitt, 2004). The reference strain (driver) for the SSH experiment was strain $\mathrm{PAO} 1$, for which the entire genome sequence is known (Stover et al., 2000). For prevalence studies, we used several categories of strain panels as reported previously (Smart et al., 2006). These comprised 12 isolates of the Midlands 1 epidemic strain, 22 LES isolates and 11 isolates of the Manchester epidemic strain, taken mainly from isolates obtained during the survey of CF isolates in England and Wales (Scott \& Pitt, 2004). Sixteen genetically distinct non-LES isolates from adult patients in Liverpool were included from our previous SSH studies (Parsons et al., 2002; Smart et al., 2006). In addition, we obtained 43 more-recent, uncharacterized, non-LES isolates (negative for the LES DNA marker PS21) from the Liverpool adult CF unit and 32 uncharacterized non-LES $\mathrm{CF}$ isolates from a neighbouring adult CF unit at Clatterbridge Hospital (Smart et al., 2006). We also screened a representative isolate of clone C (Römling et al., 1994) and strain PA14 (Rahme et al., 1995).

Construction and screening of subtraction libraries. Genomic DNA was isolated from the Midlands 1 isolate 9245 and strain PAO1 as described previously (Winstanley \& Hart, 2000). SSH was carried out using the Clontech PCR-Select Bacterial Genome Subtraction kit, essentially as recommended by the supplier but with a hybridization temperature of $73{ }^{\circ} \mathrm{C}$. In the hybridizations, DNA from the Midlands 1 strain was used as the tester and DNA from strain PAO1 was used as the driver. PCR amplicons obtained following $\mathrm{SSH}$ were cloned into pGEM-T (Invitrogen). The subtraction library of RsaI fragments thus constructed was screened by sequencing of plasmid DNA extracted from individual clones (Lark Technologies) using M13 forward and reverse vector primers. BLAST searches of the P. aeruginosa genome project website (http://www. pseudomonas.com) were used to determine the presence or absence of sequences in the PAOl genome. Tester-specific sequences were further analysed using BLASTN and BLASTX searches of the database available at http://www.ncbi.nlm.nih.gov (last accessed 27 February 2006).

PCR amplification and dot-blot screening of strains. The oligonucleotide primers (Sigma-Genosys) used in PCR assays and for the labelling of probes are listed in Table 1 along with the annealing temperatures used. PCR amplifications were carried out in an Eppendorf MasterCycler thermal cycler as described previously (Smart et al., 2006). Dot-blot hybridization of genomic DNA, extracted using Wizard Genomic DNA Purification kit columns (Promega), was carried out as described previously (Winstanley \& Hart, 2000). Digoxigenin-11-2'-dUTP (DIG) (Roche)-labelled probes were made by carrying out PCR amplification in the presence of $60 \mu \mathrm{M}$ DIG using vector or internal primers. Hybridization and subsequent detection of DIG was carried out following the manufacturer's instructions.

PFGE. PFGE of Spel-digested genomic DNA was carried out using $1 \%(\mathrm{w} / \mathrm{v})$ agarose gels and interpreted according to the protocol of Tenover et al. (1995).

\section{RESULTS AND DISCUSSION}

\section{Midlands 1 subtracted library}

SSH using the Midlands 1 isolate 9245 as tester and strain PAO1 as driver yielded a library of 54 tester-specific sequences (Table 2), $24 \%$ of which either had no significant matches in the database or shared similarity with hypothetical proteins of no known function. Of five sequences sharing similarity with bacteriophage proteins, only one matched a bacteriophage (Pf1; Hill et al., 1991) identified previously in $P$. aeruginosa (Table 2 ). This sequence (MIDSSH20) matched a Pf1 ORF not present in the genome sequence of strain PAO1. The subtraction indicated that Midlands 1 carries genes for the production of type III pyoverdine, which is the least common pyoverdine type amongst isolates of $P$. aeruginosa (de Vos et al., 2001; Parsons et al., 2002), but is shared by the two epidemic strains (LES and Midlands 1). In addition, the SSH data indicated that the Midlands 1 clone had the same serotype as the LES. Both are serotype O6, a widespread serotype (Pirnay et al., 2002). However, the presence of the $16 \mathrm{~kb}$ flagellin glycosylation island (Arora et al., 2001, 2004), coupled to our own PCR assays (unpublished data), indicated that the Midlands 1 clone, unlike the LES, is flagellin type a.

There was some evidence that the Midlands 1 clone also contains at least part of the genomic island PAGI-3 (Larbig et al., 2002; Klockgether et al., 2004). In addition, there were several subtracted sequences with similarity to proteins associated with transposition, recombination or DNA modification and genes associated with polyketide synthesis (Table 2).

\section{Distribution of subtracted sequences}

From the Midlands 1 subtraction, PCR assays were designed to determine the distribution of 14 sequences amongst Midlands 1 and other P. aeruginosa isolates. The sequences chosen had BLASTX similarity to bacteriophage-related proteins (MID1, MID-A8, MID-E8, MID-H5), a putative transposase (MID-SSH14), a siderophore receptor (MIDSSH40), a transport protein (MID-B4), an asparagine synthetase (MID-B5), a type III pyoverdine synthesis protein (MID-C3), restriction-modification proteins (MID4 and MID-C10), an ORF from the flagellin glycosylation island (MID-SSH41) and an acyltransferase (MID-F2). In addition, one sequence with no significant similarity to database sequences was included (MID-B9).

The ten Midlands 1 isolates were all PCR positive for each of the subtracted sequences present (Table 3). All of the LES isolates tested were also PCR positive for sequences MID-B4, MID-B5, MID-C3, MID-F2 and MID-SSH40. Further screening of genetically distinct non-LES isolates indicated that only Midlands 1 isolates were PCR positive for sequences MID1, MID4, MID-A8, MID-C10, MID-E8 or MID-H5 
Table 1. Oligonucleotide primers used in this study

\begin{tabular}{|c|c|c|c|c|}
\hline Primer & Sequence $\left(5^{\prime} \rightarrow 3^{\prime}\right)$ & $\begin{array}{l}\text { Amplicon } \\
\text { size (bp) }\end{array}$ & $\begin{array}{c}\text { Annealing } \\
\text { temperature } \\
\left({ }^{\circ} \mathrm{C}\right)\end{array}$ & Target \\
\hline Mid1F & TTGCGCTCCATCGTTTGA & 649 & 56 & MID1 \\
\hline Mid1R & CTCCAGATGCCTACGAAA & & & \\
\hline Mid4F2 & TTCAGGCGCGCTTCAAGA & 638 & 55 & MID4 \\
\hline Mid4R2 & ACACCTTCGATGGCCAAT & & & \\
\hline MidA8F & GAAACGCTGCTACCTGAG & 188 & 56 & MID-A8 \\
\hline MidA8R & CGTAGGTAGGACAAAAGG & & & \\
\hline MidB4F & CCAGCAAGCGGTTGTTCA & 231 & 56 & MID-B4 \\
\hline MidB4R & AAAGACTGCGCGACCAAG & & & \\
\hline MidB5F & ATTCCCGTTAGCAGGTTC & 498 & 58 & MID-B5 \\
\hline MidB5R & TGATGGCCATGGATACCC & & & \\
\hline MidB9F & AGCGTTCGTATGGTTTCG & 370 & 56 & MID-B9 \\
\hline MidB9R & AAATGGCCCAACACTACC & & & \\
\hline MidC3F & GTCAAGGCCATCAAGGAA & 326 & 56 & MID-C3 \\
\hline MidC3R & TGTATGGTCTGCTCGTCG & & & \\
\hline MidC10F & ATCACCCGGCTGTAATCA & 279 & 58 & MID-C10 \\
\hline MidC10R & GCTCACGCTGCTGTTTGT & & & \\
\hline MidE8F & TGTTTTGTGCAGGGGGTG & 604 & 56 & MID-E8 \\
\hline MidE8R & AGATGATCCAACGCGACC & & & \\
\hline MidF2F & TGATGGCCATGGCTACTG & 455 & 56 & MID-F2 \\
\hline MidF2R & CCTGAAGGATGGTCTCTG & & & \\
\hline MidF8F & CGTATCGCCCATGCTCAT & 287 & 56 & MID-F8 \\
\hline MidF8R & CTTCTGTCGTGCCATGGA & & & \\
\hline MidH5F & CCAGAGGGTTTCAGTGTG & 1024 & 58 & MID-H5 \\
\hline MidH5R & ATTTTCAGGGGCAGCAGC & & & \\
\hline MidH6F & CGTCAAGCTCCTGCAACA & 526 & 56 & MID-H6 \\
\hline MidH6R & GGTCCTTACAGCCTGATG & & & \\
\hline SSH14F & CTTCCTGATATGTGGTTC & 265 & 55 & MID-SSH14 \\
\hline SSH14R & TCGTTGCAACACCTTTGG & & & \\
\hline SSH40F & TGAGTTTGGTAGCGGGTC & 386 & 55 & MID-SSH40 \\
\hline SSH40R & GACTGACCTGTTTGGAGA & & & \\
\hline SSH41F & TGGTCAGGAAACGGCTCT & 170 & 55 & MID-SSH41 \\
\hline SSH41R & CTTGCATAGAGTGGCGTG & & & \\
\hline
\end{tabular}

(Table 3). Three of these six sequences had best BLASTX matches with bacteriophage sequences (Table 2).

On the basis of experiments using PFGE to compare strains and estimate fragment sizes, we believe that the genome of the Midlands 1 clone is smaller than that of strain PAO1 (data not shown). Previously, we also estimated that the LES genome, which carries approximately $95 \%$ of strain PAO1 genes, is no bigger than that of strain PAO1 (Salunkhe et al., 2005). The SSH analysis identified a number of genes or gene clusters likely to contribute to the accessory genome of the Midlands 1 strain, some shared with the LES. However, multilocus sequence typing suggests that the LES and Midlands 1 lineages are unrelated (Curran et al., 2004).

The MID1 subtracted sequence, matching a P4-like integrase, included at one extremity an exact match to the first 50 bp of a 77 bp tRNA ${ }^{A r g}$ (predicted gene PA0263.1) of strain PAO1. The presence in some strains of insertion sequence elements in this region has been described previously (Ernst et al., 2003). The insertion of a bacteriophage integrase gene adjacent to this tRNA locus suggests that MID1 (and MID-H5) may form one end of a prophage or genomic island in the Midlands 1 clone. BLASTX matches indicated that SSH sequence MID-A8 may reside near to the putative integrase gene (MID1 and MID-H5) in the Midlands 1 genome. The presence of these and other bacteriophage-related sequences only in Midlands 1 isolates suggests that the Midlands 1 clone contains at least one prophage not commonly carried by strains of $P$. aeruginosa.

Restriction-modification systems often vary among isolates. Our prevalence studies indicated that the restrictionmodification system matching five separate subtracted sequences may be unique to the Midlands 1 strain (Table 3).

It is possible that antimicrobial polyketides may play a role in enabling the strain to out-compete other pseudomonads. 
Table 2. Midlands $1 \mathrm{SSH}$ summary table

Sequences sharing less than $90 \%$ nucleotide sequence identity with the PAO1 genome were included in the table.

\begin{tabular}{|c|c|c|c|c|c|c|}
\hline Sequence & $\begin{array}{c}\text { Length } \\
\text { (bp) }\end{array}$ & $\begin{array}{l}\text { GC content } \\
(\mathrm{mol} \%)\end{array}$ & Best BLASTX match/comments [GenBank accession no.] & $\begin{array}{l}\text { Identity } \\
(\%)\end{array}$ & $\begin{array}{l}\text { Length } \\
\text { (aa) }\end{array}$ & $E$ value \\
\hline \multicolumn{7}{|c|}{ Bacteriophage-related } \\
\hline $\mathrm{MID1}^{*}$ & 746 & $58 \cdot 2$ & $\begin{array}{l}\text { Site-specific recombinase (N-terminal region), phage integrase family, } \\
\text { locus PFL_4977 (Pseudomonas fluorescens Pf-5) [YP_262056] }\end{array}$ & 55 & 154 & $2 e^{-42}$ \\
\hline MID-H5 & 1404 & $56 \cdot 6$ & $\begin{array}{l}\text { Site-specific recombinase (C-terminal region), phage integrase family } \\
\text { (P. fluorescens } \text { Pf-5) [YP_262056] }\end{array}$ & 54 & 114 & $2 \mathrm{e}^{-26}$ \\
\hline MID-A8 & 349 & $61 \cdot 9$ & Hypothetical protein (Nitrobacter sp.) [ZP_01044916] & 48 & 82 & $9 e^{-17}$ \\
\hline MID-SSH20 & 357 & $55 \cdot 5$ & $\begin{array}{l}\text { Bacteriophage Pf1 ORF90 ( } P \text {. aeruginosa) [CAA36337]; short } \\
\text { predicted ORF not in PAO1 }\end{array}$ & 100 & 90 & $1 \mathrm{e}^{-37}$ \\
\hline \multirow[t]{2}{*}{ MID-E8 } & 709 & $60 \cdot 1$ & $\begin{array}{l}\text { Putative transcriptional regulator, prophage CP4-57 (Azotobacter } \\
\text { vinelandii AvOP) [ZP_00415815] }\end{array}$ & 60 & 104 & $4 \mathrm{e}^{-27}$ \\
\hline & & & $\begin{array}{l}\text { Putative transcriptional regulator, prophage CP4-57 (A. vinelandii } \\
\text { AvOP) [ZP_00415816] }\end{array}$ & 80 & 63 & $7 e^{-22}$ \\
\hline \multicolumn{7}{|c|}{ Siderophore-related } \\
\hline MID-G1 & 165 & $65 \cdot 0$ & $\begin{array}{l}p v d I \text { (3), type III pyoverdine-related non-ribosomal peptide synthetase } \\
(P . \text { aeruginosa) }[\text { AY765261] }\end{array}$ & 100 & 54 & $7 e^{-26}$ \\
\hline MID-C3 & 409 & $64 \cdot 3$ & $\begin{array}{l}p v d D(3) \text {, type III pyoverdine-related non-ribosomal peptide synthetase } \\
(P . \text { aeruginosa) [AY765261] }\end{array}$ & 99 & 136 & $6 e^{-63}$ \\
\hline MID-C5 & 320 & $62 \cdot 8$ & $\begin{array}{l}\text { pvdD (3), type III pyoverdine-related non-ribosomal peptide synthetase } \\
\quad(P . \text { aeruginosa) }[\text { AY765261] }\end{array}$ & 100 & 106 & $3 e^{-56}$ \\
\hline MID-H6 & 587 & $63 \cdot 4$ & $\begin{array}{l}p v d D(3), \text { type III pyoverdine-related non-ribosomal peptide synthetase } \\
(P . \text { aeruginosa }) \text { [AY765261] }\end{array}$ & 98 & 195 & $3 e^{-98}$ \\
\hline MID-E2 & 598 & $59 \cdot 9$ & $\begin{array}{l}\text { pvdD (3), type III pyoverdine-related non-ribosomal peptide synthetase } \\
\quad(P . \text { aeruginosa) [AY765261] }\end{array}$ & 100 & 199 & $e^{-111}$ \\
\hline MID-H1 & 511 & $61 \cdot 8$ & FpvAIII; type III pyoverdine receptor (P. aeruginosa) [AAN62912] & 100 & 155 & $1 \mathrm{e}^{-88}$ \\
\hline MID-SSH40 & 461 & $54 \cdot 9$ & $\begin{array}{l}\text { Outer membrane siderophore receptor }(P \text {. aeruginosa C3719) [ZP_ } \\
\text { 00965615] }\end{array}$ & 99 & 153 & $6 e^{-88}$ \\
\hline MID-F8 & 348 & $60 \cdot 3$ & $\begin{array}{l}p v d E, \text { ABC transporter, type III pyoverdine-related }(P . \text { aeruginosa) } \\
\text { [AY765261] }\end{array}$ & 100 & 115 & $4 \mathrm{e}^{-52}$ \\
\hline \multicolumn{7}{|l|}{ O-serotype } \\
\hline MID-SSH42 & 187 & $52 \cdot 4$ & WbpO (P. aeruginosa serotype O6) [AAM27816] & 100 & 62 & $3 e^{-28}$ \\
\hline MID-B1 & 237 & $58 \cdot 7$ & $\mathrm{WbpU}$ (P. aeruginosa serotype O6) [AAM27823] & 100 & 78 & $5 e^{-39}$ \\
\hline \multicolumn{7}{|c|}{ Genomic islands } \\
\hline MID-H4 & 179 & $65 \cdot 4$ & $\begin{array}{l}\text { Hypothetical protein ORF C/SG116 (P. aeruginosa) [AAN62218]; } \\
\text { PAGI-3 genomic island }\end{array}$ & 98 & 59 & $5 e^{-28}$ \\
\hline MID-SSH41 & 221 & $58 \cdot 8$ & OrfA ( $P$. aeruginosa) [AAP35713]; flagellin glycosylation island & 100 & 73 & $1 \mathrm{e}^{-37}$ \\
\hline MID-H11 & 560 & $57 \cdot 9$ & OrfM ( $P$. aeruginosa CF5) [AAP35726]; flagellin glycosylation island & 100 & 130 & $7 e^{-70}$ \\
\hline MID-C8 & 478 & $62 \cdot 3$ & OrfM (P. aeruginosa) [AAK15338]; flagellin glycosylation island & 100 & 159 & $1 \mathrm{e}^{-87}$ \\
\hline MID-C9 & 617 & $62 \cdot 7$ & OrfM ( $P$. aeruginosa) [AAK15338]; flagellin glycosylation island & 99 & 205 & $e^{-118}$ \\
\hline \multicolumn{7}{|c|}{ Drug resistance/antimicrobial synthesis } \\
\hline MID-B4 & 310 & $64 \cdot 8$ & $\begin{array}{l}\text { Outer membrane channel protein PltN, component of ABC } \\
\text { transporter (Pseudomonas sp. M18) [AAY59070] }\end{array}$ & 99 & 103 & $6 e^{-53}$ \\
\hline MID-B3 & 361 & $61 \cdot 5$ & $\begin{array}{l}\text { Polyketide synthase type I, PltC, involved in synthesis of pyoluteorin } \\
\text { (Pseudomonas sp. M18) [AAQ90174] }\end{array}$ & 98 & 76 & $3 e^{-35}$ \\
\hline MID-C1 & 362 & $62 \cdot 7$ & $\begin{array}{l}\text { 2,4-Diacetylphloroglucinol biosynthetic protein (polyketide synthase), } \\
\text { PhlD (P. fluorescens) [AAX31636] }\end{array}$ & 78 & 120 & $5 e^{-45}$ \\
\hline \multicolumn{7}{|c|}{ DNA modification/recombination/transposases } \\
\hline MID-B10 & 813 & $64 \cdot 2$ & Possible helicase (Marinobacter aquaeolei) [ZP_00816698] & 40 & 265 & $1 e^{-37}$ \\
\hline MID-A12 & 276 & $58 \cdot 7$ & $\begin{array}{l}\text { Putative type IIII restriction enzyme, residues 29-119 (Azoarcus } \\
\text { sp. EbN1) [YP_157375] }\end{array}$ & 65 & 91 & $5 e^{-21}$ \\
\hline MID-C10 & 292 & $58 \cdot 9$ & $\begin{array}{l}\text { Putative type IIII restriction enzyme, residues 121-216 (Azoarcus } \\
\text { sp. EbN1) [YP_157375] }\end{array}$ & 87 & 96 & $2 \mathrm{e}^{-43}$ \\
\hline
\end{tabular}


Table 2. cont.

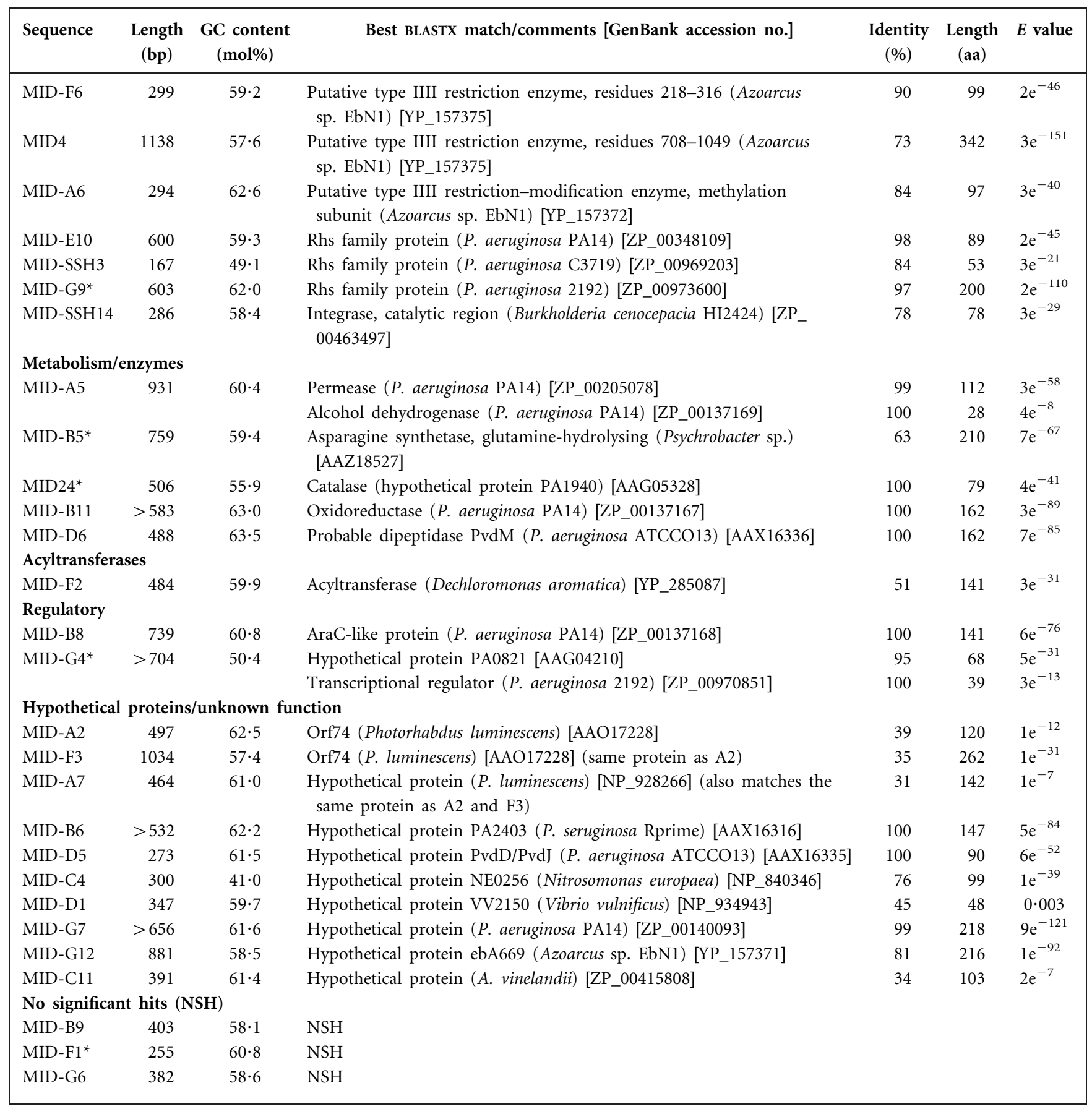

${ }^{\star}$ Partial match with $\mathrm{PAO} 1$ sequence.

Three subtracted sequences matched proteins with probable or possible roles in the production of polyketides, one of which, MID-B4, was carried by both the Midlands 1 clone and the LES.

Interestingly, very few of the subtracted sequences were carried by any of the Manchester epidemic strain isolates, suggesting that the mobilome of the Midlands 1 clone is much more closely related to that of the LES than to the
Manchester strain and that the three epidemic strains may share few novel sequences.

\section{PCR amplification assay for the detection of Midlands 1 isolates}

We further tested the MID1 PCR assay on a panel of uncharacterized non-LES isolates from the adult CF unit in Liverpool. We had no previous knowledge of the presence or 
Table 3. Distribution of subtracted sequences based on PCR amplification assays

\begin{tabular}{|c|c|c|c|c|c|c|c|c|c|c|c|c|c|c|}
\hline Isolates tested & \multicolumn{14}{|c|}{ No. of PCR positives for each MID subtracted sequence } \\
\hline LES $(n=22)$ & 0 & 0 & 0 & 0 & 0 & 0 & 22 & 22 & 0 & 22 & 22 & 0 & 22 & 0 \\
\hline Manchester $(n=11)$ & 0 & 0 & 0 & 0 & 0 & 0 & 0 & 0 & 0 & 0 & 0 & 2 & 11 & 0 \\
\hline $\begin{array}{l}\text { Non-LES isolates, genetically different } \\
(n=16)\end{array}$ & 0 & 0 & 0 & 0 & 0 & 0 & 6 & 4 & 5 & 2 & 7 & 3 & 7 & 11 \\
\hline CF isolates, Clatterbridge $(n=32)$ & 0 & ND & ND & ND & $\mathrm{ND}$ & ND & ND & ND & $\mathrm{ND}$ & ND & ND & ND & ND & ND \\
\hline PAO1 $(n=1)$ & 0 & 0 & 0 & 0 & 0 & 0 & 0 & 0 & 0 & 0 & 0 & 0 & 0 & 0 \\
\hline PA14 $(n=1)$ & 0 & 0 & 0 & 0 & 0 & 0 & 0 & 0 & 0 & 0 & 0 & 0 & 0 & 0 \\
\hline Clone C $(n=1)$ & 0 & 0 & 0 & 0 & 0 & 0 & 0 & 0 & 0 & 0 & 0 & 0 & 1 & 1 \\
\hline
\end{tabular}

ND, Not determined.

absence of the Midlands 1 genotype amongst patients in Liverpool. One of the isolates (59041) was PCR positive for MID1. The isolate was compared with a known Midlands 1 isolate using PFGE and was different by only one band (Fig. 1), confirming it as a Midlands 1 isolate.

Dot-blot hybridization was used to confirm the PCR-based distributions of both MID1 and MID4 sequences amongst five Midlands 1 isolates, strain PAO1, strain PA14, 16 genetically different non-LES isolates and representatives of the LES, the Manchester epidemic strain and clone C (data not shown).

Recently, we and others have identified a small number of non-LES isolates that are positive using the PS21 diagnostic

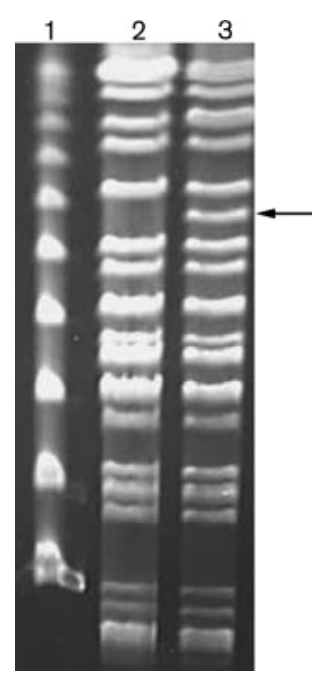

Fig. 1. PFGE typing to confirm the Midlands 1 isolate from a CF patient in Liverpool. Lanes: 1, pulse marker, 50-1000 kb (Sigma-Aldrich); 2, known Midlands 1 isolate; 3, isolate 59041. The extra band identified in isolate 59041 is indicated with an arrow. test (Lewis et al., 2005; Smart et al., 2006). There are other LES-specific PCR tests available for confirmation (Smart et al., 2006) and any positives can be confirmed subsequently with an additional typing method. However, we have observed that sequences identified as unique for LES are often not carried by all LES isolates (Parsons et al., 2002; Smart et al., 2006). This characteristic of LES populations makes it difficult to identify a single PCR test that is $100 \%$ specific and sensitive for identification. We did not observe such instability with the Midlands 1 isolates. All six Midlands 1-specific PCR tests identified in this study were positive for each of the 12 Midlands 1 isolates included. In addition, with our collection of CF isolates, representing most of the genotypes present amongst the Liverpool CF population and some beyond, we found no false positives for the Midlands 1 PCR-based test targeting sequence MID1 (phage integrase). Despite the fact that the MID1 sequence is probably associated with a bacteriophage, we found it to be stably maintained amongst our collection of Midlands 1 isolates. However, the unrelated sequence MID4 (restriction-modification enzyme) may serve as an additional, confirmatory PCR-based test. We were previously unaware of the presence of the Midlands 1 genotype amongst the Liverpool CF population, which is dominated by the LES (Panagea et al., 2003). However, having identified the strain in one patient we are now in a position to monitor its progress and take any necessary steps should the strain spread. In addition, this test will also enable others worldwide to assess their $\mathrm{CF}$ isolates for the presence of this $\mathrm{CF}$ epidemic strain.

\section{ACKNOWLEDGEMENTS}

We would like to thank Jean-Paul Pirnay and Laurence Rahme for providing strains and John Corkill for assistance with PFGE. This work was funded by the award of a grant (to C. W. and C. A. H.) by the UK Cystic Fibrosis Trust. 


\section{REFERENCES}

Armstrong, D., Bell, S., Robinson, M. \& 8 other authors (2003). Evidence for spread of a clonal strain of Pseudomonas aeruginosa among cystic fibrosis clinics. J Clin Microbiol 41, 2266-2267.

Arora, S. K., Bangera, M., Lory, S. \& Ramphal, R. (2001). A genomic island in Pseudomonas aeruginosa carries the determinants of flagellin glycosylation. Proc Natl Acad Sci U S A 98, 9342-9347.

Arora, S. K., Wolfgang, M. C., Lory, S. \& Ramphal, R. (2004). Sequence polymorphism in the glycosylation island and flagellins of Pseudomonas aeruginosa. J Bacteriol 186, 2115-2122.

Chambers, D., Scott, F., Bangur, R. \& 7 other authors (2005). Factors associated with infection by Pseudomonas aeruginosa in adult cystic fibrosis. Eur Respir J 26, 651-656.

Cheng, K., Smyth, R. L., Govan, J. R. W., Doherty, C., Winstanley, C., Denning, N., Heaf, D. P., van Saene, H. \& Hart, C. A. (1996). Spread of $\beta$-lactam-resistant Pseudomonas aeruginosa in a cystic fibrosis clinic. Lancet 348, 639-642.

Curran, B., Jonas, D., Grundmann, H., Pitt, T. \& Dowson, C. G. (2004). Development of a multilocus sequence typing scheme for the opportunistic pathogen Pseudomonas aeruginosa. J Clin Microbiol 42, 5644-5649.

de Vos, D., de Chial, M., Cochez, C., Jansen, S., Tümmler, B., Meyer, J.-M. \& Cornelis, P. (2001). Study of pyoverdine type and production by Pseudomonas aeruginosa isolated from cystic fibrosis patients: prevalence of type II pyoverdine isolates and accumulation of pyoverdine-negative mutations. Arch Microbiol 175, 384-388.

Ernst, R. K., D’Argenio, D. A., Ichikawa, J. K. \& 12 other authors (2003). Genome mosaicism is conserved but not unique in Pseudomonas aeruginosa isolates from the airways of young children with cystic fibrosis. Environ Microbiol 5, 1341-1349.

Hill, D. F., Short, N. J., Perham, R. N. \& Petersen, G. B. (1991). DNA sequence of the filamentous bacteriophage Pf1. J Mol Biol 218, 349-364.

Jones, A. M., Govan, J. R. W., Doherty, C. J., Dodd, M. E., Isalska, B. J., Stanbridge, T. N. \& Webb, A. K. (2001). Spread of a multiresistant strain of Pseudomonas aeruginosa in an adult cystic fibrosis clinic. Lancet 358, 557-558.

Klockgether, J., Reva, O., Larbig, K. \& Tümmler, B. (2004). Sequence analysis of the mobile genome island pKLC102 of Pseudomonas aeruginosa C. J Bacteriol 186, 518-534.

Larbig, K. D., Christmann, A., Johann, A., Klockgether, J., Hartsch, T., Merkl, R., Wiehlmann, L., Fritz, H.-J. \& Tümmler, B. (2002). Gene islands integrated into tRNA ${ }^{\text {Gly }}$ genes confer genome diversity on a Pseudomonas aeruginosa clone. J Bacteriol 184, 6665-6680.

Lewis, D. A., Jones, A., Parkhill, J., Speert, D. P., Govan, J. R., Lipuma, J. J., Lory, S., Webb, A. K. \& Mahenthiralingam, E. (2005). Identification of DNA markers for a transmissible Pseudomonas aeruginosa cystic fibrosis strain. Am J Respir Cell Mol Biol 33, 56-64.
O'Carroll, M. R., Syrmis, M. W., Wainwright, C. E., Greer, R. M., Mitchell, P., Coulter, C., Sloots, T. P., Nissen, M. D. \& Bell, S. C. (2004). Clonal strains of Pseudomonas aeruginosa in paediatric and adult cystic fibrosis units. Eur Respir J 24, 101-106.

Ou, H.-Y., Smith, R., Lucchini, S., Hinton, J., Chaudhuri, R. R., Pallen, M., Barer, M. R. \& Rajakumar, K. (2005). ArrayOme: a program for estimating the sizes of microarray-visualized bacterial genomes. Nucleic Acids Res 33, e3.

Panagea, S., Winstanley, C., Parsons, Y. N., Walshaw, M. J., Ledson, M. J. \& Hart, C. A. (2003). PCR-based detection of a cystic fibrosis epidemic strain of Pseudomonas aeruginosa. Mol Diagn 7, 195-200.

Parsons, Y. N., Panagea, S., Smart, C. H. M., Walshaw, M. J., Hart, C. A. \& Winstanley, C. (2002). Use of subtractive hybridization to identify a diagnostic probe for a cystic fibrosis epidemic strain of Pseudomonas aeruginosa. J Clin Microbiol 40, 4607-4611.

Pirnay, J.-P., de Vos, D., Cochez, C., Bilocq, F., Vanderkelen, A., Zizi, M., Ghysels, B. \& Cornelis, P. (2002). Pseudomonas aeruginosa displays an epidemic population structure. Environ Microbiol 4, 898-911.

Rahme, L. G., Stevens, E. J., Wolfort, S. F., Shao, J., Tompkins, R. G. \& Ausubel, F. M. (1995). Common virulence factors for bacterial pathogenicity in plants and animals. Science 268, 1899-1902.

Römling, U., Wingender, J., Müller, H. \& Tümmler, B. (1994). A major Pseudomonas aeruginosa clone common to patients and aquatic habitats. Appl Environ Microbiol 60, 1734-1738.

Salunkhe, P., Smart, C. H. M., Morgan, J. A. W., Panagea, S., Walshaw, M. J., Hart, C. A., Geffers, R., Tümmler, B. \& Winstanley, C. (2005). A cystic fibrosis epidemic strain of Pseudomonas aeruginosa displays enhanced virulence and antimicrobial resistance. J Bacteriol 187, 4908-4920.

Scott, F. W. \& Pitt, T. L. (2004). Identification and characterization of transmissible Pseudomonas aeruginosa strains in cystic fibrosis patients in England and Wales. J Med Microbiol 53, 609-615.

Smart, C. H. M., Walshaw, M. J., Hart, C. A. \& Winstanley, C. (2006). Use of suppression subtractive hybridization to examine the accessory genome of the Liverpool cystic fibrosis epidemic strain of Pseudomonas aeruginosa. J Med Microbiol 55, 677-688.

Stover, C. K., Pham, X. Q., Erwin, A. L. \& 28 other authors (2000). Complete genome sequence of Pseudomonas aeruginosa PAO1, an opportunistic pathogen. Nature 406, 959-964.

Tenover, F. C., Arbeit, R. D., Goering, R. V., Mickelsen, P. A., Murray, B. E., Persing, D. H. \& Swaminathan, B. (1995). Interpreting chromosomal DNA restriction patterns produced by pulsed-field gel electrophoresis: criteria for bacterial strain typing. J Clin Microbiol 33, 2233-2239.

Winstanley, C. (2002). Spot the difference: applications of subtractive hybridization to the study of bacterial pathogens. J Med Microbiol 51, 459-467.

Winstanley, C. \& Hart, C. A. (2000). Presence of type III secretion genes in Burkholderia pseudomallei correlates with $\mathrm{Ara}^{-}$phenotypes. J Clin Microbiol 38, 883-885. 